\title{
Student Learning Readiness in the Pandemic Era
}

\author{
Hasmiati $^{1}$, Laeli Qadrianti ${ }^{2}$, Jamaluddin $^{3}$, Nurhasanah $^{4}$, R. Nurhayati ${ }^{5}$ \\ \{miaelbugis@gmail.com ${ }^{1}$, laeliqadrianti@gmail.com ${ }^{2}$ \} \\ Faculty of Tarbiyah and Teacher Training, Islamic Institute of Muhammadiyah Sinjai, Indonesia ${ }^{1,2,3,4,5}$
}

\begin{abstract}
The purpose of this study was to determine student learning readiness in the pandemic era. The type of this research was a qualitative descriptive study, using a phenomenological approach. The research subjects were 25 students of Faculty Tarbiyah and Teaching Training of IAIM Sinjai. The research subjects were selected based on preliminary observations of the problem under study. The research instruments were observation and interviews. The data analysis technique in this study was the interactive model of Miles and Huberman, where data analysis was carried out during data collection and after data collection in a certain period. The analysis stage includes data reduction, data presentation, and verification or conclusion. The results of this study indicate that the student's learning readiness in the current pandemic era has two sides, namely positive and negative sides. However, the interview analysis tends to be on the negative side, it meant that the students were not ready to do online learning. Viewed from the aspect of emotional readiness. In addition, empirical data found the students were not all financially well off.
\end{abstract}

Keywords: Readiness level, student learning, pandemic era

\section{Introduction}

Technological advances have an impact change to many things are no exception in the field of education. Information Technology has revolutionized the way of learning today, where learning at this time is not limited to space class but has gone beyond geography and also time $[1]$.

Learning readiness is the overall state of student readiness, family readiness and school readiness (United Nations International Children's Emergency Fund [UNICEF], 2012; United States Department of Health and Human Services [USDHHS], 2014) where all the circumstances are favorable for students and they ultimately lead them to want to learn immediately. The student readiness is that individual state of student where he or she is physically, mentally and emotionally ready to learn. Similarly, the school readiness is defined as that complete preparedness of school (entire teachers) to create a favorable environment (United Nations Educational, Scientific and Cultural Organization [UNESCO], 2007) which to achieve the best learning among their students [2].

In supporting the expected teaching and learning process, it is necessary to pay attention to the learning readiness of students first. "Learning readiness is the degree of concentration and eagerness to learn among students" [3]. Readiness to learn according to [5], the state of capacity that exists in students in relation to certain teaching goals. In line with the opinion of [6], "Not yet ready, don't learn, learning can't be careless or by force, the name is not ready. People who are not ready to learn are like people who want to pour water, but the shelter has not been prepared so that water is wasted in vain" [7],[8] namely: physical condition, mental condition, 
emotional condition, needs (motivation) and knowledge. The COVID-19 pandemic has not only affected adults, but also children. Restrictions on physical interaction space (physical distancing) that take place during the pandemic put mental or psychosocial pressure on children. In general, they complain about several things: the children are already at the saturation level of being at home for a long time, while the internet connection facilities are inadequate [9],[10].

Related to this situation also requires a lot of adjustments that need to be made, especially the learning process. This means that educators are required to be able to maintain physical stamina and mental energy, but also be able to maintain significant learning quality in the midst of these conditions, as well as to work around so that learning objectives can be optimally conveyed and absorbed by students.

Based on preliminary data from the student body of the Muhammadiyah Sinjai Islamic Institute, $80 \%$ of students come from areas where network usage is not adequate, and economic conditions are still below standard so that it is not possible to conduct distance learning using learning applications that require high data. lots and good network quality [11],[12]. In addition, initial observations show that many students respond negatively if the lecturer requires students to use applications that do not support student devices. Based on this initial data, researchers conducted research on student learning readiness in the current pandemic era.

The results of the study are expected to provide an offer for the application of an effective learning model during distance learning. In addition, the results of this study also become the attention of education observers to cover all problems that arise during distance learning, so as to be able to provide practical solutions for handling distance learning.

\section{Method}

This type of research is descriptive qualitative research, using a phenomenological approach. The research subjects were 25 students of the Faculty of Tarbiyah and Teacher Training IAIM Sinjai. Research subjects were selected based on initial observations of the problems studied. As for the research instruments are observations and interviews. Data analysis technique in this study is the interactive model of Miles and Huberman, namely data analysis is carried out during data collection, and after data collection within a certain period. 1) Data reduction, namely summarizing and selecting the main things and focusing on the things that are important and looking for themes that are considered important and relevant to the research subject. 2) Display or data presentation, namely the presentation of data in the form of short descriptions, charts, and the like which is a continuation after the data is reduced. 3) Verification or conclusion. Verification is drawing conclusions after the data is patterned, focused and arranged systematically in the form of a narrative, then through the induction method, the data is concluded. So that the meaning of the data can be found in the form of interpretation and argumentation. Conclusions were also verified during the study.

\section{Results and Discussions}

\subsection{Student Readiness}

Every individual always experiences a learning process in his life, by learning will allow individuals to experience changes in themselves. These changes include mastery of skills and 
changes in attitude. Indicators of learning readiness are seen from several aspects, namely physical conditions, mental conditions, emotional conditions, needs (motivation) and knowledge.

\subsection{Learning Readiness Analysis}

\section{Readiness Physical Condition}

In general, the physical condition of students is ready to learn. This was obtained from interviews with all respondents who said they were ready. As stated by respondent (5) below,

"With my healthy body condition and have the desire to learn and have the tools to learn."

Based on the interview with respondent (5), it was found that physically students are ready to learn.

\section{Mental Readiness}

The readiness of students' mental conditions can be reflected in their desire to participate in the learning process. Students prepare all the needs and learning needs.

This is in line with interviews with respondents (7), stating that:

"In my opinion, online learning has not been able to match offline learning, where since offline learning takes place very often I have to find a network to be able to join the learning process and when the lecturer explains, I often can't focus due to many distractions from the environment where I sit studying, It is different when studying directly on campus, where the facilities and infrastructure are indeed available so that no one else can interfere with learning."

Based on interviews with respondents, it is known that students mentally prefer to learn face-to-face, compared to online learning.

\section{Emotional Condition Readiness}

The current emotional condition of students while participating in virtual-based learning (online), generally states that it is not interesting to carry out virtual learning. Lack of understanding of the material obtained, because they did not get a direct explanation from the lecturer.

This is in accordance with the statement of the respondent (1),

"Online learning doesn't appeal to us."

This opinion is in line with the statement of the respondent (2),

"Online learning is between interesting and not, depending on the material and lecturers who teach."

Based on the results of the interview, it is known that emotionally, students state that online learning is not interesting, if the lecturer's teaching method and the material presented is not varied.

\section{Readiness Needs (motivation) and Knowledge}

Regarding student learning motivation during virtual learning, students feel unmotivated, just because online learning during a pandemic is a must, a necessity that creates compulsion.

Respondent's statement (3), stated that, "I am not motivated to take online lectures." 
The lack of student motivation to take online lectures is influenced by several factors, related to funding issues (internet quotas), network problems if they are in areas that have inadequate network quality.

However, there are also respondents who see the positive side of this online learning phenomenon. This can be seen in the statement of the respondent (10), stating that:

"I am quite motivated, because online learning has taught me the importance of appreciating the time together when we are together and face to face with lecturers and friends. In addition, my motivation for learning during the pandemic is that I can attend many seminars and webinars from various places, so that I can still gain knowledge and experience."

\subsection{Discussion}

The readiness of students to study in the current pandemic era is still a topic of discussion for all circles. Readiness to learn includes physical conditions, mental conditions, emotional conditions, needs (motivation) and knowledge. Judging from the physical condition, students are ready to learn, students have a healthy physique to study. However, currently students are in a very tired condition because of the intensity of interacting online. Related to eye health problems that are tired when you have to stare at a cellphone or computer screen when learning using videos.

Students' learning readiness is seen from the readiness of their mental condition, students mentally prefer to learn face-to-face, compared to online learning.

Judging from the readiness of students' emotional conditions, it is known that students feel that online learning is not interesting, if the lecturer's teaching method is not varied and the material presented is not well controlled by the lecturer concerned.

Readiness to learn in terms of conditions of need (motivation) and knowledge, students are motivated enough to gain knowledge. However, high motivation, but not supported by other supporting elements such as data quotas and good network quality, then this remains an obstacle in the learning process. Especially learning during the current pandemic.

\section{Conclusion}

Based on the results of interview data analysis, it was found that the study readiness of students in the current pandemic era has two sides, namely positive and negative sides. However, the interview analysis tends to be on the negative side, meaning that students are not ready to do online learning.

\section{Acknowledgment}

This research was supported by the Institute for Research and Community Service (LP2M) through research grants. Thank you to all those who have helped in this research process. 


\section{References}

[1] Djamarah, Syaiful Bahri, 2008, Rahasia Sukses Belajar. Jakarta: Rineka Cipta.

[2] Indah Purwandani, Analisa Tingkat Kesiapan E-Learning (E-Learning Readiness) Studi Kasus: Amik Bina Sarana Informatika Jakarta, Jurnal Bianglala Informatika, Vol. 5 No. 2, 2017, h. 102 107.

[3] Oemar Hamalik, 2003, Perencanaan Pengajaran Berdasarkan Pendekatan Sistem. Jakarta: Bumi Aksara.

[4] Rita Dangol dan Milan Shrestha, Learning Readiness and Educational Achievement among School Students, The International Journal of Indian Psychology, Volume 7, Issue 2, DIP: 18.01.056/20190702 DOI: 10.25215/0702.056, h. 468-476.

[5] Slameto, 2015, Belajar dan Faktor-faktor yang Mempengaruhinya. Jakarta: Rineka Cipta.

[6] Sugiyono. (2013). Memahami Penelitian Kualitatif, Bandung: Alfabeta.

[7] United Nations Educational, Scientific and Cultural Organization. (2007). EFA global monitoring report 2007: Strong foundations - early childhood care and education. Paris: Author.

[8] United Nations International Children's Emergency Fund. (2012). A school readiness: A conceptual framework. New York: Author

[9] United States Department of Health and Human Services. (2014). Components of readiness. Retrieved from http://aspe.hhs.gov/report/willingable-ready-basics-and-policyimplicationsreadiness-key-components.

[10] Hapsari, S.M.; Sugito, S.; Fauziah, P.Y. Parent's involvement in early childhood education during the covid-19 pandemic period. J. Progress. Educ. 2020, 10, 298-311.

[11] Aliyyah, R.R.; Rachmadtullah, R.; Samsudin, A.; Syaodih, E.; Nurtanto, M.; Tambunan, A.R.S. The perception of primary school teachers of online learning during the covid-19 pandemic period: A case study in Indonesia. J. Ethn. Cult. Stud. 2020, 7, 90-109. 3. Asvial, M.; Mayangsari, J.; Yudistriansyah, A. Behavioral intention of e-learning: A case study of distance learning at a junior high school in Indonesia due to the covid-19 pandemic. Int. J. Technol. 2021, 12, 54-64

[12] Ariyanti, G.; Santoso, F.G.I. Analysis of mathematics learning outcomes on senior high school student in Madiun city, Indonesia in covid-19 pandemic. J. Phys. Conf. Ser. 2020, 1663, 1-6 